Пігарєв Юрій Борисович кандидат фізико-математичних наук, доцент, завідувач кафедри електронного урядування та інформаційних систем ОРІДУ НАДУ при Президентові України, м. Одеса, 65062, вул. Генуезька, 22, тел.: (050) 490-46-51, e-mail: pigarev51 @ gmail.com, https://orcid.org/0000-0003$3501-8342$

Костенюк Наталя Іванівна кандидат наук з державного управління, старший викладач кафедри електронного урядування та інформаційних систем, ОРІДУ НАДУ при Президентові України, вул. Генуезька, 22, м. Одеса, 65062, тел.: (050) 391-13-54, e-mail: k_natali72@ukr.net, https://orcid.org/0000-0001-6723-7166

\title{
ЦИФРОВА ТРАНСФОРМАЦІЯ ЯК ОСНОВА РОЗВИТКУ ПУБЛІЧНОГО УПРАВЛІННЯ ТА АДМІНІСТРУВАННЯ
}

Анотація. У статті розкрито умови та необхідність цифрової трансформації моделі як основи розвитку публічного управління, проаналізовані основні етапи цифрової трансформації в публічному управлінні та адмініструванні. Встановлена необхідність реалізації трьох основних принципів цифрової трансформації публічного управління та адміністрування, зокрема: структурно-функціональний, інформаційнокомунікативний, організаційно-технологічний. Розглянуто, що під цифровою платформою слід розуміти інтелектуальну структурну одиницю, функція якої полягає в управлінні кожним учасником або елементом механізму системи за допомогою закладених принципів. Так, цифрова трансформація має ряд переваг 3 огляду на скорочення рівнів ієрархії системи публічного управління, а також збільшення швидкості протікання всіх управлінських процесів. Серед ключових вимог до цифрової трансформації публічного управління розглядаються різні характеристики, які відображають результати впровадження цифрових технологій в діяльність органів публічного управління. Орієнтація цифрової трансформації публічного управління та адміністрування напрямлена на забезпечення та підвищення результативності та ефективності діяльності органів публічної влади. Цифрова трансформація в Україні реалізується на основі розробки i використання різних інформаційних технологій, за допомогою яких відбувається розширення можливостей оброблення великих масивів інформації, також вона дозволяе систематизувати та впорядкувати різні спрямовані інформаційні потоки, які підтримуються в наданні та споживанні публічних послуг при аналізі оцінки результативності та ефективності публічних послуг, а також ступеня доцільності та продуктивності використання фінансових коштів. Отже, в Україні необхідно впровадити 
нову моделі публічного управління та адміністрування, яка враховувала б усі виклики цифрової трансформації, завдання розробки цифрової платформи, яка буде ефективною в умовах розвитку економіки України.

Ключові слова: органи публічної влади, публічне управління та адміністрування, результативність, цифрова платформа, цифрова трансформація

Pigarev Yuri Borysovych Candidate of Physics and Mathematics, Docent, Head of the Department of Electronic Management and Information Systems, ORIPA NAPA under the President of Ukraine, 65062, Odessa, Genuezka, 22, тел.:(050) 490-46-51, e-mail: pigarev51@gmail.com, https://orcid.org/ 0000-00033501-8342

Kosteniuk Natalia Ivanivna Candidate of Public Administration, Senior lecturer E-Government and Information Systems Department Odessa Regional Institute for Public Administration of the National Academy for Public Administration under the President, 65062, Odessa, Genuezka, 22,tel.: (050) 39113-54, e-mail: k_natali72@ukr.net,https://orcid.org/0000-0001-6723-7166

\title{
DIGITAL TRANSFORMATION YAK BASIS FOR RELEASE OF PUBLIC MANAGEMENT TA ADMINISTRUVANNYA
}

\begin{abstract}
At the statti of rozkrito think about the need for digital transformation of the model as the basis for the development of public administration, analyzed the main stages of digital transformation in public administration and administration. The need for the implementation of three basic principles of digital transformation of public administration and administration, architecture has been established: structural and functional, information and communication, organizational and technological. It is seen that the digital platform follows the intelligence and the intellectual structural unit, the function of which field is controlled by a skin participant or an element of the mechanism of the system, based on additional principles. So, the digital transformation can take a number of changes from looking at the speed of development of the public administration system, as well as the improvement of the speed of communication through all management processes. In the middle of the key technologies before the digital transformation of public administration, we look at the characteristics that represent the results of the introduction of digital technologies into the work of public administration bodies. The organization of digital transformation of public administration and administration is focused on securing and improving the effectiveness and efficiency of public authorities. Digital transformation in Ukraïni realizuetsya on osnovi rozrobki i vikoristannya riznih informatsiynih tehnologiy for Relief yakih vidbuvaєtsya rozshirennya mozhlivostey obroblennya great masiviv Informácie, takozh Won dozvolyaє sistematizuvati that vporyadkuvati rizni spryamovani informatsiyni flows SSMSC pidtrimuyutsya in nadanni that spozhivanni publichnih poslug at analizi otsinki rezultativnosti that efektivnosti
\end{abstract}


public services, as well as the steps of adolescence and productivity of financial goals. Also, in Ukraine, it is necessary to introduce a new model of public administration and administration, like a vrahovuval for a digital transformation wiki, the establishment of digital platforms in the minds of the development of the Ukrainian market.

Keywords: organization of public authority, public administration and administration, performance, digital platform, digital transformation

Постановка проблеми. 3 розвитком та застосуванням цифрових технологій з'являються нові можливості досягнення основних цілей соціально-економічного розвитку України. Для їх реалізації велике значення має розвиток цифрової трансформації в публічному управлінні та адмініструванні. На даний час в Україні здійснюється практична діяльність, яка напрямлена на розвиток в публічному управлінні цифрових технологій. Також здійснюється розвиток та використання новітніх цифрових технологій в публічному управлінні, тобто цифрова трансформація публічного управління. Серед ключових вимог до цифрової трансформації публічного управління розглядаються різні характеристики, які відображають результати впровадження цифрових технологій в діяльність органів публічного управління.

Аналіз останніх досліджень i публікацій. Проблеми цифрової трансформації публічного управління та адміністрування та розвитку електронного урядування широко висвітлюються в науковій літературі такими вітчизняними вченими, як Т. Биркович, В. Биркович, В. Дрешпак, Н. Грицяк, О. Кабанець, О. Карпенко, П. Клімушин, В. Куйбіда, I. Лопушинський, В. Наместнік, О. Орлов, Г. Почепцов та багатьма іншими.

Мета статті - дослідження цифрової трансформації як розвиток публічного управління та адміністрування.

Виклад основного матеріалу. Сучасна управлінські, економічні та соціальні зміни в значній мірі обумовлена цифровими технологіями, що трансформують спосіб людського життя та алгоритми функціонування підприємств і органів публічної влади. Враховуючи прискорений вплив інформаційних технологій на суспільство, взаємопроникнення різних сфер та напрямів, межі дії публічного управління на підпорядковані об'єкти стають нечіткими. Цифрова трансформація публічного управління є організаційними та суспільними змінами на основі впровадження цифрових технологій в усі аспекти взаємодії влади з людиною [1].

Трансформаційні зміни виявляються в разі виникнення інноваційних методів роботи в процесі використання технологій, що заміщує просте розширення або підтримку традиційних підходів. Орієнтація цифрової трансформації публічного управління та адміністрування напрямлена на забезпечення та підвищення результативності та ефективності діяльності органів публічної влади.

Тому для підвищення достовірності, результативності та надійності інформаційних даних доцільно об'єднати різні інформаційні джерела та 
забезпечити надання користувачам відповідно до їх вимог до якості відповідної інформації, що потребує координації зусиль різних суб'єктів, компетентних у вирішенні даної проблеми. Одним 3 найважливіших напрямків в цифровому публічному управлінні $\epsilon$ створення єдиного інформаційного простору для органів публічної влади, населення, приватного бізнесу та громадських організацій як рівноправних суб'єктів управління [2].

Вважається, що даний підхід дозволить підвищити ефективність публічного управління на всіх рівнях. Потреба в подоланні низки негативних тенденцій та необхідність вирішення проблем, що перешкоджають становленню України як цифрової держави, вимагають проведення реформ в першу чергу в сфері публічного управління.

Тому для аналізу поняття цифрової трансформації в публічному можна відокремити наступні основні етапи цифрової трансформації в публічному управлінні та адмініструванні:

- оцифрування процесів, в рамках якого здійснюється впровадження традиційних цифрових технологій для підвищення ефективності діяльності органів публічної влади, та управління відкритими даними;

- електронний уряд, що припускає впровадження цифрових технологій, особливо заснованих на використанні інтернету, для вдосконалення діяльності органів публічної влади;

- цифрове урядування, при якому новітні цифрові технології дозволяють враховувати переваги користувачів при формуванні складу електронних послуг, що надаються і процедур, пов'язаних з їх отриманням [3].

Цифрова трансформація це не просто інструмент реалізації стратегії модернізації публічного управління та адміністрування, а й значна міра, яка визначає напрями удосконалення діяльності органів публічної влади. Цифрова трансформація може удосконалити процеси планування діяльності органів публічного управління, моніторингу та оцінки їі результатів. Для планування, моніторингу та оцінки результативності, а також ефективності діяльності органів публічної влади найчастіше використовуються цифрові платформи, особливо в частині моніторингу та оцінки якості надання публічних послуг [4].

На етапі проведення оцінки діяльності органів публічної влади важливу роль відіграє впровадження механізмів розробки публічної політики, яка заснована на критеріях ефективності та результативності діяльності. Склад критеріїв передбачає проведення детального аналізу їх діяльності, що вимагає наявності програмного забезпечення та використання сучасних цифрових технологій.

Програмне забезпечення дозволяє автоматизувати процес планування, моніторингу, оцінки результативності та ефективності діяльності органів публічної влади на всіх етапах управлінського циклу. Так, органи публічної влади за допомогою сучасного цифрового продукту розробляють i затверджують в електронному вигляді плани результативності та ефективності діяльності державних службовців і здійснюють моніторинг їх 
виконання, направляють зворотний зв'язок і проводять оцінку. Оптимізуючи цей процес, сучасне програмне забезпечення дозволяє органам влади приділяти основну увагу результатами, а також забезпечувати управління результативністю в режимі реального часу [5].

Таким чином, цифрова трансформація може змінити традиційні підходи до планування, моніторингу та оцінки результатів діяльності органів публічної влади. Об'єднання даних 3 різних джерел, робота 3 неструктурованими i частково структурованими джерелами інформації, постійного збору інформації, зворотній зв'язок, моніторинг та оцінка державного регулювання дозволяють державі більш якісно виявляти i вирішувати проблеми сьогодення, прогнозувати і своєчасно реагувати на проблеми майбутнього.

Основу цифрової трансформації становить технологічний аспект, набори даних і бізнес-моделі як рушійні сили, що лежать в основі зазначеної трансформації, і спираються на аналіз «векторів» цифрової трансформації у багатьох сферах політики. Структура включає сім взаємопов'язаних вимірів політики: доступ; використання; інноваційність; робочі місця; соціальне процвітання; довіра; відкритість ринку. Використання переваг та вирішення проблем цифрової трансформації вимагає координації в усіх сферах політики, що передбачає розгляд питань, які дотичні до інших аспектів структурної політики [6].

Цифрова трансформація визначає процеси вдосконалення способів аналітичної діяльності органів публічної влади різних інформаційних даних, що $є$ одним 3 головних чинників подальшого інноваційного перетворення способів побудови публічно-управлінських комунікацій. Тим самим, умови здійснення цифрових змін методів прийняття управлінських рішень виступають основою оптимального перетворення способів використання елементів цифрового простору в діяльності органів публічної влади до застосування засобів регулювання інформаційних потоків в мережі Інтернет iз застосуванням цифрових технологій.

Таке застосування визначає необхідність реалізації трьох основних принципів цифрової трансформації публічного управління та адміністрування:

1. Структурно-функціональні, тобто децентралізація та оптимальний розподіл функцій i ресурсів в публічному управлінні, облік економічної специфіки управлінням територіями.

2. Інформаційно-комунікативні, тобто технологічна результативність i безпека інформаційних комунікацій, модернізація інформаційнотехнологічної інфраструктури, стійкість і безперервність інформаційних комунікацій; інформаційна узгодженість управлінських рішень.

3. Організаційно-технологічні, тобто оптимальне поєднання децентралізації, субсидіарності, структурування інформаційних даних [1].

В якості джерел цифрової трансформації публічного управління є:

1) цифрове забезпечення;

2) бюджетне фінансування; 
3) правове регулювання використання інформаційних систем;

4) розробка спеціалізованих вимог до процедур закупівлі товарів i послуг за допомогою цифрових технологій.

Ці джерела виступають ключовими факторами подальшого формування необхідною для здійснення цифрової трансформації, що дозволяють здійснювати безперервний обмін інформаційними даними в системі публічного співробітництва.

3 огляду на специфіку діяльності органів публічної влади, можна виділити кілька різновидів цифрових платформ, які мають функціональне призначення [5]:

1. Пошукові системи, що надають розширені можливості здійснення електронної комерції, що виявляється в прискореному зіставленні цін на різні продукти виробництва, які мають різні якісно-кількісні параметри.

2. Корпоративні платформи, що формують цифрову організацію управління в системі функціонування підрозділів органів публічної влади 3 наданням комплексних публічних послуг з урахуванням реалізації державних закупівель та розміщення замовлень в секторі економіки.

3. Технологічні платформи, що являються сукупністю засобів цифрової систематизації, процесів здійснення управлінських рішень при виконанні функцій проектування управлінськими процесами, використання спеціалізованих операційних систем i інфраструктури зберігання інформаційних даних.

4. Інструментальні платформи, що складаються з комплексу програмноінформаційних продуктів, що дозволяють розробляти програмні рішення управлінського характеру. Застосування таких платформ виступають засобом в сфері публічного управління при здійсненні управлінських функцій.

5. Цифрова інфраструктура, що діє за допомогою активності суб'єктів ринку інформатизації, що забезпечує державне регулювання процесу ринкових відносин, в яких беруть участь суб'єкти малого і середнього бізнесу 3 підвищенням рівня цифрового забезпечення їх діяльності із застосуванням новітніх цифрових технологій.

6. Прикладні платформи, що мають економічну основу у вигляді інформатизованого алгоритму обміну інформації між підрозділами органів публічної влади за допомогою проведення транзакцій в єдиному цифровому середовищі [7].

Застосування цифрових платформ в діяльності органів публічної влади розширює функціональні можливості, так як за допомогою використання сучасних цифрових технологій можна отримати наступні результати:

1) значно знижені фінансові витрати при надання управлінських послуг;

2) прискорення реалізації необхідних інновацій в електронному забезпеченні публічної діяльності;

3) удосконалення інформаційних комунікацій в діяльності органів публічної влади з метою забезпечення обміну необхідною інформацією. 
4) формування спеціального простору діяльності для онлайнпосередників, здатних створити продуктивну цифрову площадку, за допомогою якої посадові особи органів публічної влади здатні підтримувати контакти з представниками малого та великого бізнесу [8].

Отже, дані цифрові трансформації у публічному управлінні дозволяють провести модернізацію системи публічного управління з метою побудови цифрового адміністрування, заснованого на взаємодії 3 структурними елементами публічного управління та суб'єктами малого та великого бізнесу.

Таким чином, цифрова трансформація діяльності органів публічного управління 3 метою підвищення ступеня цифрового забезпечення управлінських функцій може виражатися в наступних заходах:

1) узагальнення можливостей мереж цифрової взаємодії i багатоканального узгодження різних точок зору на одну i ту ж проблему в системі розробки і прийняття офіційних управлінських рішень;

2) формування цифрової бази обробки значних масивів вихідних даних;

3) розширення форм застосування технологій цифрової трансформації в діяльності органів публічної влади;

4) використання хмарних технологій для зберігання інформації.

5) організація запобігання та усунення кіберзагроз при підтримці правового характеру за допомогою використання інформаційних ресурсів;

6) формування і подальший розвиток режиму «відкритого вікна» для надання публічних послуг.

Серед основних факторів, що впливають на процес цифрової трансформації публічного управління, можна виділити [6]:

- активне впровадження нових знань та глобальних інформаційних технологій у всі сфери суспільного життя;

- розвиток громадського суспільства та соціального партнерства в цифровому середовищі;

- особливості створеної моделі ринкової економіки, які виражаються у стимулюванні свободи підприємництва, вільного руху робочої сили, конкурентності ринків;

- ступінь децентралізації влади та ефективність проведення структурної та регіональної політики для поліпшення соціально-економічних умов життя громадян;

- ступінь розвитку економіки країни, який визначає матеріальні можливості людей щодо використання сучасних інформаційних технічних засобів;

- реалізація соціально значущих проектів, що сприяють дотриманню принципів соціальної рівності та справедливості в цифровій економіці [6].

Таким чином, цифрова трансформація в Україні реалізується на основі розробки і використання різних інформаційних технологій, за допомогою яких відбувається розширення можливостей оброблення великих масивів інформації. Цифрова трансформація публічного управління дозволяє систематизувати та впорядкувати різні спрямовані інформаційні потоки, які підтримуються в наданні та споживанні публічних послуг при аналізі оцінки 
результативності та ефективності публічних послуг, а також ступеня доцільності та продуктивності використання фінансових коштів. При чіткому структурному функціонуванні інформаційних технологій створюється єдиний цифровий простір, в якому забезпечується впорядковане публічне співробітництво [4].

Висновки. Функціонування системи публічного управління характеризується певним рівнем якості, яке втілюється в виявленні аналізу, оцінки i вирішення соціально-економічних проблем в житті населення i діяльності бізнесу на основі наявних ресурсів та цифрових технологій як сукупність органів публічного управління. Цифрова трансформація діяльності органів публічної влади здійснюється на основі джерел трансформації, що характеризується застосуванням сучасних цифрових технологій при необхідному рівні фінансування, правового регулювання.

Принципи цифрової трансформації публічного управління діляться на три категорії в залежності від специфіки засобів своєї реалізації відповідно до функціональної діяльності, використанням інформаційних комунікацій та технологією взаємодії структурних підрозділів органів публічного управління. В системі публічного управління використовуються різні цифрові технології, за допомогою яких розширюються можливості обробки масивів інформації в сфері публічного партнерства.

\section{Лimepamypa:}

1. Берназюк О. Роль та місце цифрових технологій у сфері публічного управління // Інформаційне право. 2017. №10

2. Цифрова адженда України - 2020 («Цифровий порядок денний» - 2020): Концептуальні засади (версія 1.0). URL: https://ucci.org.ua/uploads/files/58e78ee3c3922.pdf.

3. Бабаєв В., Стадник Г., Момот Т. Цифрова трансформація у сфері вищої освіти в умовах глобалізації. Комунальне господарство міст. 2019. Т. 2. № 148.

4. Куйбіда В. С., Карпенко О. В., Карпенко О. В., Наместнік В. В. Цифрове врядування в Україні: базові дефініції понятійно-категоріального апарату. Вісн. НАДУ. Серія "Державне управління". 2018. № 1. С. 5-11.

5. Цифрове врядування : монографія / О. В. Карпенко, Ж. 3. Денисюк, В. В. Наместнік [та ін.] ; за. ред. О. В. Карпенка. Київ : ІДЕЯ ПРИНТ, 2020. 336 с.

6. Биркович T.I., Биркович В.І., Кабанець О.С. Механізми публічного управління у сфері цифрових трансформацій. Державне управління: удосконалення та розвиток. 2019.№ 9 .

7. Квітка С. Цифрові трансформації як сучасний тренд періодичного циклу розвитку суспільства. Збірник наукових праць Національної академії державного управління при Президентові України. Спецвипуск. 2020. С. 131-134.

\section{References:}

1. Bernaziuk, O. (2017). Rol ta mistse tsyfrovykh tekhnolohii u sferi publichnoho upravlinnia [The role and place of digital technologies in the field of public administration]. Pidpryiemnytstvo, hospodarstvo i pravo - Entrepreneurship, Economy and Law, 10(260), 166170 [in Ukrainian].

2. Tsyfrova adzhenda Ukrainy - 2020 («Tsyfrovyi poriadok dennyi» - 2020): Kontseptualni zasady (versiia 1.0) [Digital Agenda of Ukraine - 2020 ("Digital Agenda" - 2020): 
Conceptual principles (version 1.0)]. (2016). ucci.org.ua. Retrieved from https://ucci.org.ua/uploads/files/58e78ee3c3922.pdf [in Ukrainian].

3. Babaiev, V., Stadnyk, H., Momot, T. (2019). Tsyfrova transformatsiia u sferi vyshchoi osvity $\mathrm{v}$ umovakh hlobalizatsii [Digital transformation in higher education in the context of globalization]. Komunalne hospodarstvo mist - Municipal utilities, 2(148), 2-9 [in Ukrainian].

4. Kuibida, V. S., Karpenko, O. V., Karpenko, O. V., Namestnik, V. V. (2018). Tsyfrove vriaduvannia v Ukraini: bazovi definitsii poniatiino-katehorialnoho aparatu [Digital governance in Ukraine: basic definitions of the conceptual and categorical apparatus]. Visn. NADU. Seriia "Derzhavne upravlinnia" - Bulletin of the National Academy of Public Administration under the President of Ukraine. Public Administration Series, 1, 5-11 [in Ukrainian].

5. Karpenko, O. V., Denysiuk, Zh. Z., Namestnik, V. V., et al. (2020). Tsyfrove vriaduvannia [Digital governance]. Kyiv: IDEIa PRYNT [in Ukrainian].

6. Byrkovych, T.I., Byrkovych, V.I., Kabanets, O.S. (2019). Mekhanizmy publichnoho upravlinnia u sferi tsyfrovykh transformatsii [Mechanisms of public administration in the field of digital transformations]. Derzhavne upravlinnia: udoskonalennia ta rozvytok - Public administration: improvement and development, 9, 166-170 [in Ukrainian].

7. Kvitka, S. (2020). Tsyfrovi transformatsii yak suchasnyi trend periodychnoho tsyklu rozvytku suspilstva [Digital transformations as a modern trend of the periodic cycle of society]. Zbirnyk naukovykh prats Natsionalnoi akademii derzhavnoho upravlinnia pry Prezydentovi Ukrainy - Collection of scientific works of the National Academy of Public Administration under the President of Ukraine, Special issue, 131-134 [in Ukrainian]. 